\title{
Ruminal ammonia concentration and fermentation kinetics of commercial herbal feed additives with amino acids
}

\section{Cinética de liberación de nitrógeno amoniacal y fermentación ruminal de aditivos para piensos a base de hierbas con aminoácidos}

\author{
Angélica Valeria Lorenzana Moreno ${ }^{1}$, María Eugenia de la Torre Hernández ${ }^{1}$, Augusto \\ César Lizarazo Chaparro ${ }^{2}$, Fernando Xicoténcatl Plata Pérez ${ }^{1}$, Luis Alberto Miranda \\ Romero $^{3}$, José Antonio Martínez García ${ }^{1}$, Germán David Mendoza Martínez ${ }^{1}$
}

Originales: Recepción: 30/09/2019 - Aceptación: 23/10/2020

\begin{abstract}
The objective of this study was to characterize the chemical composition of rumen fermentation while estimating it's in vitro protein degradation (from ruminal ammonia concentration) and kinetics regarding two herbal feed plant additives. The tested herbal mixtures were elaborated with Phaseolus mango and Linum usitatissimum, providing lysine (Lys) and Trigonella foenum-graecum and Allium sativa, providing Methionine (Met). They were compared to alfalfa (Medicago sativa) and solvent extracted soybean meal (Glicine max), as standard sources of protein using the in vitro gas production technique modified to estimate $\mathrm{N}-\mathrm{NH}_{3}$, recording fermentation kinetics and dry matter digestibility (72 h), in a completely randomized design followed by Tukey test. Ruminal ammonia concentration in the herbal mixtures was lower $(P<0.05)$ than in the standard protein sources, indicating that protein from herbal mixtures could resist ruminal degradation. Herbal additives with Lys or Met showed minimum $\mathrm{N}-\mathrm{NH}_{3}$ concentration in the first $4 \mathrm{~h}$ of incubation. At $8 \mathrm{~h}$, the concentration was 0.27 and $0.54 \mathrm{mg} \mathrm{dL}^{-1}$ for the herbal products with Lys and Met, significantly lower than solvent extracted soybean meal and alfalfa (1.15 and $2.24 \mathrm{mg} \mathrm{dL}^{-1}$ respectively, $P<0.05)$.
\end{abstract}

\section{Keywords}

Allium sativa $\bullet$ Feed plant additive $\bullet$ Linum usitatissimum $\bullet$ lysine $\bullet$ methionine $\bullet$ ammonia nitrogen $\bullet$ Phaseolus mango $\bullet$ protein $\bullet$ rumen $\bullet$ Trigonella foenum-graecum

1 Universidad Autónoma Metropolitan. Unidad Xochimilco. Calzada del Hueso 1100. Villa Quietud.04960. Coyoacán. CDMX, México.mdelatorre@correo.xoc.uam.mx

2 Universidad Nacional Autónoma de México. Centro de Enseñanza Práctica e Investigación en Producción y Salud Animal.

3 Universidad Autónoma de Chapingo. Departamento de Zootecnia. 


\section{RESUMEN}

El objetivo del estudio fue caracterizar la composición química, estimar la degradación de la proteína in vitro (a partir de la concentración de $\mathrm{N}$ amoniacal) y los parámetros de cinética de fermentación ruminal de dos aditivos herbales. Las mezclas herbales probadas están elaboradas con Phaseolus mango y Linum usitatissimum, para aportar lisina (Lis), y con Trigonella foenum-graecum y Allium sativa, para aportar metionina (Met), mismas que fueron comparadas con alfalfa (Medicago sativa) y harina de soya extraída con solvente (Glycine max), como fuentes estándar de proteína, usando la técnica de producción de gas in vitro modificada para liberación de $\mathrm{N}-\mathrm{NH}_{3}$, estimando la cinética de fermentación y la digestibilidad de materia seca (72 h) en un diseño completamente al azar, con prueba de medias de Tukey. La concentración de $\mathrm{N}$ amoniacal de las mezclas herbales fue menor $(P<0,05)$ que las fuentes de proteínas estándar, lo que indica que su proteína podría resistir la degradación ruminal. Los aditivos herbales con Lis o Met mostraron una concentración mínima de $\mathrm{N}-\mathrm{NH}_{3}$ en las primeras $4 \mathrm{~h}$ de incubación; a las $8 \mathrm{~h}$ la liberación, para dichos productos fue de 0,27 y $0,54 \mathrm{mg} \mathrm{dL}^{-1}$ respectivamente, menor $(P<0,05)$ que la harina de soya extraída con solvente y alfalfa $\left(1,15\right.$ y $2,24 \mathrm{mg} \mathrm{dL}^{-1}$ respectivamente).

\section{Palabras clave}

Allium sativa • Aditivo herbal • Linum usitatissimum • lisina • metionina • nitrógeno amoniacal • Phaseolus mango • proteína • rumen • Trigonella foenum-graecum

\section{INTRODUCTION}

Estimation of protein degradation for evaluation of feeds and calculation of the escape protein value of a particular protein, is necessary for formulating and meeting ruminant requirements $(15,39)$. Amino acids absorbed in the small intestine of ruminants derive from microbial protein and from dietary protein that escape ruminal degradation. In weaned young ruminants, a smaller rumen size (compared to the adult) limits dry matter intake and consequently microbial protein synthesis, resulting in the duodenal flow of microbial amino acids theoretically not being adequate to reach maximum growth potential $(38,39)$. Protein composition reaching the small intestine is also of great relevance given that microbial protein is considered limited in certain amino acids such as lysine, methionine and threonine, for growing ruminants $(9,47)$. Therefore, dietary undegradable rumen protein should contain amino acids that could complement the microbial contribution $(38,44)$.

Protein in plant products degrades extensively in the rumen. However, several herbaceous legumes such as Phaseolus spp and Trigonella spp have high concentrations of polyphenolic compounds (mainly tannins) and other secondary metabolites, that allow some protection from ruminal microorganisms. These tannins affect bacterial populations, improving ruminal fermentation efficiency, performing as natural feed additives $(22,25)$. These plants could increase amino acid absorption in the intestine. However, evidence about ruminal degradation and characterization of this type of species, is scarce. Therefore, the objective of the present study was to characterize two sources of herbal mixtures containing limiting amino acids (Lys and Met), analyze their chemical compositions, estimate ruminal protein degradation using ruminal ammonia concentration compared with known feeds as standard sources of protein (alfalfa and solvent extracted soybean meal) and characterize the kinetics of rumen dry matter degradation with the in vitro gas production technique.

\section{MATERIALS AND METHODS}

Two herbal mixtures were tested: one from Phaseolus mango and Linum usitatissimum (as contributor of herbal lysine; HL) and another from Trigonella foenum-graecum and Allium sativa (as herbal methionine; HM), in addition to alfalfa (Medicago sativa) and solvent extracted soybean meal (Glycine max), as standard sources of protein. The four protein substrates (HL, HM, alfalfa and solvent extracted soybean meal) were independently tested. 
OptiMethionine and OptiLysine, corresponding to HM y HL respectively, were provided by Nuproxa Mexico (Indian Herbs and Nuproxa Switzerland). These feed plant additives are standardized products and have certified mixtures, following ISO 9001 and GMP (Good Manufacturing Practices).

Herbal products composition was determined using the methodology established by the A.O.A.C. (3): humidity percentage (method 934.01), crude protein by Kjeldahl method (N x 6.25) (method 954.01), ether extract (method 920.39) and ashes by calcination at $550{ }^{\circ} \mathrm{C}$ (method 923.03). Neutral detergent fiber (NDF) and acid detergent fiber (ADF) were determined using the Van Soest et al. procedures (1991).

In vitro gas production was determined according to Theodorou et al. (1994) modified in order to measure ammoniacal nitrogen. Rumen liquor was collected from a cannulated Holstein bull, about five years old and weighing $600 \mathrm{~kg}$. Ruminal fluid was filtered through eight layers of cheesecloth and held under $\mathrm{CO}_{2}$ in a water-bath at $39^{\circ} \mathrm{C}$. A $0.5 \mathrm{~g}$ sample was placed in $125 \mathrm{~mL}$ amber flasks. Gas pressure was measured at 2, 4, 6, 8, 12, 16, 20, 24, 30, $36,42,48,60$ and $72 \mathrm{~h}$ of incubation, using a manual pressure gauge (scale 0 to $1 \mathrm{~kg} \mathrm{~cm}^{-2}$ ). Gas pressure was then transformed into volume through the linear equation proposed by Ørskov and McDonald (1979). Gas production kinetics, namely maximum volume of gas produced (Vmax), Lag phase (L), gas production rate $(\mathrm{S})$ and time required to reach half Vmax $\left(\mathrm{K}_{0.5}\right)$, were obtained using the logistic model of Pitt et al. (1999). In vitro dry matter digestibility (IVDMD) was estimated by filtering the residue from the flasks after 72 hours of incubation with a filter paper Waltham No. 41 and dried at $55^{\circ} \mathrm{C}$ for $48 \mathrm{~h}$.

$\mathrm{N}-\mathrm{NH}_{3}$ concentration was determined by the in vitro gas production test (described above), extracting $1.2 \mathrm{~mL}$ of ruminal fluid from each incubated flask at 2, 4, 8, 12 and $24 \mathrm{~h}$ of incubation and mixing with $0.3 \mathrm{~mL}$ of metaphosphoric acid, kept at $-18{ }^{\circ} \mathrm{C}$. Later, the samples were centrifuged at 12,100 x g for 5 minutes in a Mini-spin eppendorf centrifuge. The supernatant was used to measure $\mathrm{N}_{-} \mathrm{NH}_{3}$ concentration with the phenol-hypochlorite reaction (26). Readings were made at $630 \mathrm{~nm}$ with a spectrophotometer (Cary $100 \mathrm{UV}$-VIS). The results were multiplied by the sample dilution factor $(4: 1)$.

Incubation was performed twice. Each assay contained three replicates per tested substrate and their respective blanks. The experimental design was completely randomized with 4 treatments (HL, HM, solvent extracted soybean meal and alfalfa) and 6 repetitions per variable (Vmax, L, S, $\mathrm{K}_{0.5}$, IVDMD, as well as the $\mathrm{N}_{-\mathrm{NH}_{3}}$ concentration at 4, 8, 12 and 24 hours). Each flask used in gas production tests was considered an experimental unit. Data were analyzed with the JMP statistical software (42) and the means were compared with the Tukey test $(P<0.05)$.

\section{RESULTS AND DISCUSSION}

Chemical composition was similar between herbal mixtures (table 1, page 291). Considering that their formulation contains at least one legume (P. mango or T. foenum-graecum), crude protein percentage could have been higher than the value determined $(20,43,44)$. However, the exact proportion in which these legumes and their plant parts are present in the herbal mixture, are unknown. Pinto et al. (2010) mentioned that forage chemical composition can be affected by specie, forage age, plant organ (fruits or leaves), growth site and soil type, among others. The tested herbal mixtures are certified by an amino acid formulation (lysine or methionine) analysis. 
Table 1. Partial chemical composition of herbal mixtures.

Tabla 1. Composición química parcial de las mezclas herbales.

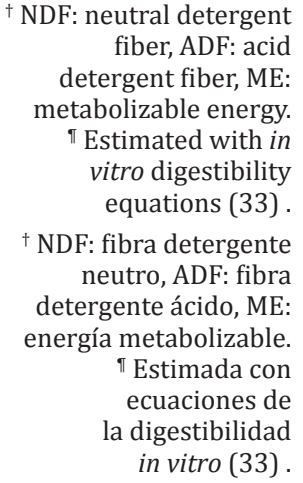

\begin{tabular}{|l|c|c|}
\hline \multicolumn{1}{|c|}{ Item } & Herbal lysine (HL) & Herbal methionine (HM) \\
\hline Dry matter (\%) & 96.0 & 97.8 \\
\hline Organic matter (\%) & 92.6 & 85.0 \\
\hline Crude protein (\%) & 8.2 & 9.2 \\
\hline NDF (\%) ${ }^{\dagger}$ & 52.6 & 44.1 \\
\hline ADF (\%) & 33.1 & 25.9 \\
\hline Ether extract (\%) & 6.7 & 4.8 \\
\hline Calcium (\%) & 1.44 & 0.97 \\
\hline Phosphorus (\%) & 0.44 & 0.54 \\
\hline Methionine (g/100g protein) & 1.74 & 5.23 \\
\hline Lysine (g/100g protein) & 11.19 & 0.81 \\
\hline ME (Mcal kg ${ }^{-1}$ ) & 2.57 & 3.02 \\
\hline
\end{tabular}

Kassi et al. (2000) explained that high concentrations of neutral detergent fiber (NDF) in forage are associated with lower intake, and high concentrations of acid detergent fiber (ADF) are associated with low ruminal digestibility, both undesirable characteristics reflected in the results of IVDMD in table 2. Legumes like P. mango have an advantage over grasses, because they mainly lignify their stems and not their leaves, as most grasses used for grazing. Therefore, greater stability in forage nutritional quality of woody legume species, is observed over time (7). These herbal mixtures are composed by finely ground herbs, therefore the effective NDF contribution is low, with minimal intake or digestion effects.

Legumes are considered a good source of protein, essential amino acids (such as lysine, leucine, isoleucine, phenylalanine and valine), unsaturated fatty acids (like linolenic and linoleic acids), dietary fiber, minerals ( $\mathrm{Ca}, \mathrm{Fe}$ and $\mathrm{Zn}$ ) and vitamin $\mathrm{C}(4,13,14,20)$, as well as various secondary metabolites. The species included in the mixtures evaluated, provide good metabolite diversity. The genus Phaseolus contains protease inhibitors, phytic acid (11) and polyphenols, as well as condensed tannins and flavonoids (anthocyanin glycosides: cyanidine, definidine and pelargonidine) $(11,20)$. L. usitatissimum contains polyunsaturated oils, mainly linolenic acid, as well as polyphenolic compounds, called lignans, with antioxidant activity $(6,12)$. The legume $T$. foenum-graecum, has antioxidant effects given by glutathione, $\beta$-carotenes and $\alpha$-tocopherol, as well as tannins, alkaloids and saponins, particularly diosgenin $(30,50)$. Finally, A. sativum is a rich source of essential oils and organosulphurous compounds such as allicin, with specific antimicrobial activities. Total phenols, condensed tannins and essential oils present in this plant appear to be biologically active secondary metabolites, which modify rumen fermentation $(22,23,34)$ and explain the resistance to protein degradation in the in vitro incubation.

Table 2. Kinetic parameters of ruminal fermentation and in vitro digestibility from herbal mixtures and protein sources.

Tabla 2. Parámetros de cinética de fermentación ruminal in vitro y digestibilidad de mezclas herbales y fuentes proteicas.

\begin{tabular}{|l|c|c|c|c|c|}
\hline \multirow{2}{*}{ Parameter } & \multicolumn{5}{|c|}{ Source $^{\dagger}$} \\
\cline { 2 - 6 } & HL & HM & SM & A & SEM \\
\hline $\mathrm{Vmax}^{72}\left(\mathrm{~mL} \mathrm{~g}^{-1}\right)$ & $292.07^{\mathrm{b}}$ & $327.77^{\mathrm{ab}}$ & $340.67^{\mathrm{a}}$ & $290.43^{\mathrm{b}}$ & 7.541 \\
\hline $\mathrm{S}\left(\mathrm{h}^{-1}\right)$ & $0.038^{\mathrm{c}}$ & $0.044^{\mathrm{ab}}$ & $0.039^{\mathrm{bc}}$ & $0.046^{\mathrm{a}}$ & 0.0012 \\
\hline $\mathrm{L}(\mathrm{h})$ & $0.83^{\mathrm{c}}$ & $1.06^{\mathrm{c}}$ & $2.22^{\mathrm{b}}$ & $2.97^{\mathrm{a}}$ & 0.265 \\
\hline $\mathrm{K}_{0.5}(\mathrm{~h})$ & $18.46^{\mathrm{a}}$ & $15.59^{\mathrm{bc}}$ & $17.47^{\mathrm{ab}}$ & $15.04^{\mathrm{c}}$ & 0.472 \\
\hline $\mathrm{IVDMD}^{72}(\%)$ & $75.60^{\mathrm{d}}$ & $83.89^{\mathrm{b}}$ & $97.69^{\mathrm{a}}$ & $78.51^{\mathrm{c}}$ & 2.565 \\
\hline
\end{tabular}

${ }^{\dagger} \mathrm{HL}$ : herbal lysine, HM: herbal methionine, SM: solvent extracted soybean meal, A: alfalfa, Vmax: maximum volume, S: fractional rate, $\mathrm{L}$ : Lag phase, $\mathrm{K}_{05}$ : time required to reach half of Vmax, IVDMD: in vitro dry matter digestibility, SEM: Standard error of mean. ${ }^{\mathrm{abc}}$ Means with different literals in the same row are different $(\mathrm{P}<0.05)$.

HL: Lisina herbal, HM: metionina herbal, SM: harina de soya extraída con solvente, A: alfalfa, Vmax: volumen máximo, $\mathrm{S}$ : tasa fraccional, L: fase lag, $\mathrm{K}_{0.5}$ : tiempo requerido para alcanzar la mitad de Vmax, IVDMD: digestibilidad in vitro de la materia seca, SEM: error estándar de la media. ${ }^{\text {abc }}$ Medias con diferente literal en la misma hilera son diferentes $(\mathrm{P}<0,05)$. 
Ruminal fermentation parameters are shown in table 2 (page 291). Solvent extracted soybean meal generated the highest gas production, probably due to the type of carbohydrates of the substrate since cellulose predominates in alfalfa and herbal mixtures. Soto et al. (1994) found that peptides and amino acids addition had no effect on ruminal fermentation parameters in vitro when bacteria is grown on cellulose-rich substrates. However, bacterial growth was stimulated with cellobiose or glucose. Although not statistically significant, gas production of herbal lysine was lower than that of herbal methionine, coinciding with Hernández et al. (2010), who explainedthat leaves with lower energy value generate less gas in vitro.

It has generally been observed that forages have a longer lag phase, especially when being of poor quality (2). However, although the herbal compounds analyzed in the present study have similar composition to that of any other forage, they have a very short lag phase, shorter than that determined for solvent extracted soybean meal and alfalfa, which can be explained by the proportion of its cellular contents.

Table 3 shows that $\mathrm{N}-\mathrm{NH}_{3}$ concentration achieved by herbal mixtures (HL and HM) was very low during the first $12 \mathrm{~h}$ of incubation compared to protein standards, remaining constant from the 4th hour of incubation. Raab et al. (1983) and Lorenz et al. (2011) reported that $\mathrm{N}-\mathrm{NH}_{3}$ concentration can be an estimator of protein degradation in the rumen. Therefore, these results would imply that part of the protein contained in these forages is resistant to rumen degradation.

Table 3. Ruminal N-NH $\mathrm{N}_{3}$ concentration $\left(\mathrm{mg} \mathrm{dL}^{-1}\right)$ from herbal mixtures and protein sources incubated in vitro.

Tabla 3. Concentración ruminal de $\mathrm{N}-\mathrm{NH}_{3}\left(\mathrm{mg} \mathrm{dL}^{-1}\right)$ de mezclas herbales y fuentes proteicas incubadas in vitro.

\begin{tabular}{|c|c|c|c|c|c|}
\hline \multirow{2}{*}{ Time h } & \multicolumn{5}{|c|}{ Source $^{\dagger}$} \\
\cline { 2 - 6 } & HL & HM & SM & A & SEM \\
\hline 4 & $0.00^{\mathrm{c}}$ & $0.02^{\mathrm{c}}$ & $1.15^{\mathrm{b}}$ & $2.24^{\mathrm{a}}$ & 0.154 \\
\hline 8 & $0.27^{\mathrm{b}}$ & $0.54^{\mathrm{b}}$ & $2.76^{\mathrm{a}}$ & $3.33^{\mathrm{a}}$ & 0.339 \\
\hline 12 & $0.34^{\mathrm{b}}$ & $0.57^{\mathrm{b}}$ & $5.19^{\mathrm{a}}$ & $4.75^{\mathrm{a}}$ & 0.245 \\
\hline 24 & $4.23^{\mathrm{b}}$ & $3.43^{\mathrm{b}}$ & $16.94^{\mathrm{a}}$ & $6.74^{\mathrm{b}}$ & 1.233 \\
\hline
\end{tabular}

${ }^{\dagger}$ HL: herbal lysine, HM: herbal methionine, SM: solvent extracted soybean meal, A: alfalfa, SEM: Standard error of mean. ${ }^{\text {abc }}$ Means with different literals in the same row are different $(P<0.05)$

${ }^{\dagger}$ HL: Lisina herbal, HM: metionina herbal, SM: harina de soya extraída con solvente, A: alfalfa, SEM: error estándard de la media. ${ }^{\mathrm{abc}}$ Medias con diferente literal en la misma hilera son diferentes $(P<0,05)$.

Rates of rumen protein degradation depend on multiple factors. Bach et al. (2005) mention protein structure, interaction with other nutrients and proteolytic activity of the ruminal microbiota as key factors, among others. However, enzymatic inhibitors or anti-nutritional factors may influence protein degradation $(27,40)$. The most studied antinutritional factors are tannins, followed by secondary plant metabolites such as saponins, cyanogenic compounds, lecithins, alkaloids, oxalic acid and flavonoids $(18,19,29)$. These factors can influence rumen protein degradation and synthesis, either by directly affecting the ruminal microorganisms, or by their interaction with nutrients $(8,22,27)$.

Plants like $P$. mungo, T. foenum-graecum and $A$. sativum, contain significant amounts of condensed tannins, that react with proteins forming tannin-protein complexes through hydrogen bonds, hydrophobic interactions, ionic bonds and covalent bonds (41). These complexes can affect bacterial enzymes inhibiting carbohydrate and protein fermentation (16). In addition, tannins affect rumen proteolysis given that they can associate with soluble dietary proteins, protecting them from microbial action $(8,16,41)$.

It has been reported that $100 \mathrm{~g}$ of $T$. foenum-graecum provides $4.63 \mathrm{~g}$ of saponins $(1,50)$. Hu et al. (2005) found that when the amount of saponins in an in vitro fermentation test is increased, the concentration of ammonia decreases significantly. Wang et al. (2000) also observed a decrease in $\mathrm{N}-\mathrm{NH}_{3}$ by including Yucca schidigera (a product rich in saponins), both in vivo (sheep feeding) and in vitro. 
Various secondary metabolites have been identified when reducing the protozoan population. Total polyphenols, condensed tannins and saponins, were all reported as secondary metabolites of forages used in the herbal mixtures of the present study. Galindo and Marrarero (2005) reported the effect of Leucaena leucocephala, Enterolobium cyclocarpum, Gliricidia sepium, Sapindus saponaria and other plants on rumen ciliated protozoa. Given that protozoa have high protein requirements, and ruminal $\mathrm{N}-\mathrm{NH}_{3}$ concentrations decrease with defaunation, this has been considered advantageous in low protein diets (31).

Decreasing rumen protein degradation of herbal mixtures (table 3, page 292) represents an advantage. Coomer et al. (1993) and De Almeida et al. (2015) statedthat supplementing young ruminants' diet with undegradable rumen protein, can increase protein and amino acid flow to the lower gastrointestinal tract and, therefore, increase the metabolizable protein supply. These herbal mixtures could be used as additives, not as protein supplement. To feed diets that maintain the concentration of $\mathrm{N}_{-} \mathrm{NH}_{3}$ for microbial protein synthesis between 4 to $10.0 \mathrm{mg}$ of $\mathrm{N}-\mathrm{NH}_{3} / 100 \mathrm{~mL}$ of rumen fluid, as well as to provide available energy for the ruminal ecosystem (41), is important. Ammonia values from the herbal mixtures in the first $12 \mathrm{~h}$ were below these values compared to the standard protein (table 3, page 292). Galindo and Marrarero (2005) mention that some legumes have soluble proteins, highly degradable in rumen, making it necessary to guarantee enough energy for adequate synthesis of microbial protein. Ruminal $\mathrm{N}-\mathrm{NH}_{3}$ concentration has been used to estimate rumen degradation (37) and lambs supplemented with herbal lysine have improved growth (28) confirming resistance to rumen degradation of the feed plant additive.

\section{Conclusions}

Ammonia concentrations found in the present study would imply that part of the protein contained in these forages is resistant to rumen degradation. Herbal mixtures evaluated could be used in ruminants feed as a source of undegradable rumen protein. However, the potential use as amino acid bypass for ruminants, needs further evaluation, in order to assess its degradation throughout the entire digestive tract.

\section{REFERENCES}

1. Aasim, M.; Baloch, F. S.; Nadeem, M. A.; Bakhsh, A.; Sameeullah, M.; Day, S. 2018. Fenugreek (Trigonella foenum-graecum L.): An underutilized edible plant of modern world. In: Global perspectives on underutilized crops. M. Ozturk, R. Hakeem, M. Ashraf, and M. Ahmad (eds). Springer. Cham. p: 381-408.

2. Amjed, M.; Jung, H. G.; Donker, J. D. 1992. Effect of alkaline hydrogen peroxide treatment on cell wall composition and digestion kinetics of sugarcane residues and wheat straw. J. Anim. Sci. 70(9): 2877-2884.

3. A.O.A.C. 2007. Association of official analytical chemists. Official methods of analysis. $17^{\text {th }}$ ed. Washington. D.C. USA.

4. Arros, F.; Garrido, C.; Valenzuela, C. 2020. Development and characterization of nettle-leaves powder (Urtica urens) as a potential supplement for animal feed. Revista de la Facultad de Ciencias Agrarias. Universidad Nacional de Cuyo. Mendoza. Argentina. 52(1): 353-359.

5. Bach, A.; Calsamiglia, S.; Stern, M. D. 2005. Nitrogen metabolism in the rumen. J. Dairy Sci. 88: E9-E21.

6. Beltagi, H. S.; Salama, Z. A.; El-Hariri, D. M. 2007. Evaluation of fatty acids profile and the content of some secondary metabolites in seeds of different flax cultivars (Linum usitatissimum L.). Gen. Appl. Plant Physiology. 33(3-4): 187-202.

7. Botero, R.; Russo, R. 1998. Utilización de árboles y arbustos fijadores de nitrógeno en sistemas sostenibles de producción animal en suelos ácidos tropicales. (FAO). Agroforestería para la producción animal en Latinoamérica. http://www.fao.org/ag/aga/agap/FRG/ AGROFOR1/Agrofor1.htm (Fecha de consulta: 30/07/2019).

8. Castro, M. J.; Westreicher, K. E.; Henke, A.; Diaby, M.; Susenbeth, A.; Dickhoefer, U. 2017. In vitro microbial protein synthesis, ruminal degradation and post-ruminal digestibility of crude protein of dairy rations containing Quebracho tannin extract. J. Anim. Physiol. Anim. Nutr. 102(1): 77-86.

9. Coomer, J. C.; Amos, H. E.; Froestschel, M. A.; Ragland, K. K.; Williams, C. C. 1993. Effects of supplemental protein source on ruminal fermentation, protein degradation and amino acid absorption in steers and on grow and feed efficiency in steers and heifers. J. Anim. Sci. 71(11): 3078-3086. 
10. De Almeida, L. M.; Detmann, E.; Gomes, D. I.; Reis, W. L.; Batista, E. D.; Campos, V. S.; Paulino, M. F. 2016. Intake, digestibility and nitrogen utilization in cattle fed tropical forage and supplemented with protein in the rumen, abomasum, or both. J. Anim. Sci. Biotech. 7(1): 11.

11. Espinosa, A. L.; Lygin, A.; Widholm, J. M.; Valverde, M. E.; Paredes, L. O. 2006. Polyphenols in wild and weedy Mexican common beans (Phaseolus vulgaris L.). J. Agric Food Chem. 54(12): 4436-4444.

12. Gagnon, N.; Cortes, C.; Da Silva, D.; Kazama, R.; Benchaar, C.; Dos Santos, G.; Zeoula, L.; Petit, H. V. 2009. Ruminal metabolism of flaxseed (Linum usitatissimum) lignans to the mammalian lignan enterolactone and its concentration in ruminal fluid, plasma, urine and milk of dairy cows. Br. J. Nutr. 102(7): 1015-1023.

13. Galindo, J.; Marrarero, Y. 2005. Manipulación de la fermentación ruminal. Revista Cubana de Ciencia Agrícola. 39: 439-450.

14. Guzmán, M. S.; Acosta, G. J.; Paredes, L. O. 2000. Protein and mineral content of a novel collection of wild and weedy common bean (Phaseolus vulgaris L). J. Sci. Food Agric. 80(13): 1874-1881.

15. Hedqvist, H.; Udén, P. 2006. Measurement of soluble protein degradation in the rumen. Anim. Feed Sci. Technol. 126(1-2): 1-21.

16. Henke, A.; Dickhoefer, U.; Westreicher-Kristen, E.; Knappstein, K.; Molkentin, J.; Hasler, M.; Susenbeth, A. 2017. Effect of dietary Quebracho tannin extract on feed intake, digestibility, excretion of urinary purine derivates and milk production in dairy cows. Arch. Anim. Nutr. 71(1): 37-53.

17. Hernández, H. J.; Guerra F. J.; Camacho, R. J.; Villarreal, E. O.; Pedraza, O. R.; Plata, P. F.; Mendoza, M. G. 2010. Evaluación de vainas y hojas de árboles forrajeros por la técnica de producción de gas in vitro. Zootecnia. Trop. 28(3): 421-426.

18. Hu, W. L.; Liu, J. X.; Ye, J. A.; Wu, Y. M.; Guo, Y. Q. 2005. Effect of tea saponin on rumen fermentation in vitro. Anim. Feed Sci. Technol. 120(3-4): 333-339.

19. Kamra, D. N.; Agarwal, N.; Chaudhary, L. C. 2006. Inhibition of ruminal methanogenesis by tropical plants containing secondary compounds. International Congress Series. 1293: 156-163.

20. Kan, L.; Nie, S.; Hu, J.; Wang, S.; Cui, W. S.; Li, Y.; Xu, S.; Wu, Y.; Wang, J.; Bai, Z.; Xie, M. 2017. Nutrients, phytochemicals and antioxidant activities of 26 kidney bean cultivars. Food Chem. Toxicol. 108: 467-477.

21. Kassi, A. L.; Newbold, C. J.; Wallace, R. J. 2000. Chemical composition and degradation characteristics of foliage of some African multipurpose trees. Anim. Feed Sci. Technol. 86(1-2): 27-37.

22. Knowless, M. M.; Pabón, M. L.; Hess, H. D.; Carulla, J. E. 2017. Changes in in vitro ruminal and postruminal degradation of tropical tannin rich legumes due to varying levels of polyethylene glycol. J. Anim. Physiol. Anim. Nutr. 101(14): 641-648.

23. Lawal, B.; Shittu, O. K.; Oibiokpa, F. I.; Mohammed, H.; Umar, S. I.; Haruna, G. M. 2016. Antimicrobial evaluation, acute and sub-acute toxicity studies of Allium sativum. J. Acute Disease. 5(4): 296-301.

24. Lorenz, M. M.; Karlsson, L.; Hetta, M.; Udén, P. 2011. Recycling of microbial N estimation of protein degradation by in vitro gas production. Anim. Feed Sci. Technol. 170(1-2): 111-116.

25. Manh, N. S.; Wanapat, M.; Uriyapongson, S.; Khejornsart, P.; Chanthakhoun, V. 2012. Effect of eucalyptus (Camaldulensis) leaf meal powder on rumen fermentation characteristics in cattle fed on rice straw. Afr. J. Agric. Res. 7(13): 1997-2003.

26. McCullough, H. 1967. The determination of ammonia in whole blood by a direct colorimetric method. Clín. Chim. Acta. 17(2): 297-304.

27. McSweeney, C. S.; Palmer, B.; McNeill, D. M.; Krause, D. O. 2001. Microbial interactions with tannins: nutritional consequences for ruminants. Anim. Feed Sci. Technol. 91(1-2): 83-93.

28. Mejía, D. M.; Mendoza, M. G; Lee, R. H.; Osorio, T. A.; Hernández, G. P. 2019. Effect of an herbal lysine source on lamb's growth. Rev. Acad. Ciênc. Anim. 17(1):199.

29. Mendoza, G. D.; Oviedo, M. F.; Pinos, J. M.; Lee-Rangel, H. A.; Vázquez, A.; Flores, R.; Pérez, F.; Roque, A.; Cifuentes, 0. 2020. Milk production in dairy cows supplemented with herbal choline and methionine. Revista de la Facultad de Ciencias Agrarias. Universidad Nacional de Cuyo. Mendoza. Argentina. 52(1): 332-343.

30. Mukthamba, P.; Srinivasan, K. 2016. Hypolipidemic and antioxidant effects of dietary fenugreek (Trigonella foenum-graecum) seeds and garlic (Allium sativum) in high-fat fed rats. Food Biosci. 14: 1-9.

31. Nhan, N. T.; Hon, N. V.; Ngu, N. T.; Von, N. T.; Preston, T. R.; Leng, R. A. 2001. Practical application of defaunation of cattle on farms in Vietnam: response of young cattle fed rice straw and grass to a single drench of groundnut oil. Asian-Australas J. Anim. Sci. 14(4): 485-490.

32. Ørskov, E. R.; McDonald, I. D. 1979. The estimation of protein degradability in the rumen from incubation measurements weighted according to rate of passage. J. Agric. Sci. 92(2): 499-503.

33. Osorio, T. I.; Mendoza, G. D.; Plata, F. X.; Martínez, J. A.; Vargas, L.; Ortega, G. C. 2015. A simulation model to predict body weight gain in lambs fed high-grain diets. Small Rumin Res. 123(23): 246-250.

34. Patra, A. K.; Kamra, D. N.; Bhar, R.; Kumar, R.; Agarwal, N. 2011. Effect of Terminalia chebula and Allium sativum on in vivo methane emission by sheep. J. Anim. Physiol. Anim. Nutr. 95(2): 187-191. 
35. Pinto, R.; Hernández, D.; Gómez, H.; Cobos, M. A.; Quiroga, R.; Pezo, D. 2010. Árboles forrajeros de tres regiones ganaderas de Chiapas, México: usos y características nutricionales. Universidad y Ciencia. 26(1): 19-31.

36. Pitt, R. E.; Cross, T. L.; Pell, A. N.; Schofield, P.; Doane, P. H. 1999. Use of in vitro gas production models in ruminal kinetics. Math. Biosci. 159(2): 145-163.

37. Raab, L.; Cafantaris, B.; Jilg, T.; Menke, K. H. 1983. Rumen protein degradation and biosynthesis. A new method for determination of protein degradation in rumen fluid in vitro. Br. J. Nutr. 50(3): 569-582.

38. Raja, A. I.; Abbasi, F.; Abd, M. E.; Abdel-Lafit, M. A.; Soomro, R. N.; Hayat, K.; Mohamed, M. A.; Bodinga, B. M.; Yao, J.; Cao, Y. 2018. Critical analysis of excessive utilization of crude protein in ruminants ration: impact on environmental ecosystem and opportunities of supplementation of limiting amino acids-a review. Environ. Sci. Pollut. Res. 25(1): 181-190.

39. Reis, W. L.; Detmann, E.; Batista, E. D.; Rufino, L. M.; Gomes, D. I.; Bento, C. B.; Mantovani, H. C.; Valladares, F. S. 2016. Effects of ruminal and post-ruminal protein supplementation in cattle fed tropical forages on insoluble fiber degradation, activity of fibrolytic enzymes, and the ruminal microbial community profile. Anim. Feed Sci. Technol. 218: 1-16.

40. Reyes-Gutiérrez, J. A.; Montañez-Valdez, O. D.; Guerra-Medina, C. E.; Ley de Coss, A. 2020. Effect of protein source on in situ digestibility of sugarcane silage-based diets. Revista de la Facultad de Ciencias Agrarias. Universidad Nacional de Cuyo. Mendoza. Argentina. 52(1): 344-352.

41. Rodríguez, R.; Sosa, A.; Rodríguez, Y. 2007. Microbial protein synthesis in rumen and its importance to ruminants. Cuban J. Agric. Sci. 41(4): 287-294.

42. Sall, J.; Lehman, A.; Stephens, M.; Creighton, L. 2012. JMP® Start Statistics: A Guide to Statistics and Data Analysis. $5^{\text {th }}$ ed. SAS Institute Inc. Cary, NC. USA.

43. Santacoloma, V. L.; Granados, M. J.; Aguirre, F. S. 2017. Evaluación de variables agronómicas, calidad del forraje y contenido de taninos condensados de la leguminosa Lotus corniculatus en respuesta a biofertilizante y fertilización química en condiciones agroecológicas de trópico alto andino colombiano. Entramado. 13(1): 222-233.

44. Soltan, Y. A.; Morsy, A. S.; Sallam, S. M.; Louvandini, H.; Abdalla, A. L. 2012. Comparative in vitro evaluation of forage legumes (Prosopis, Acacia, Atriplex and Leucaena) on ruminal fermentation and methanogenesis. J. Anim. Feed Sci. 21(4): 759-772.

45. Soto, R. C.; Muhammed, S. A.; Newbold, C. J.; Stewart, C. S.; Wallace, R. J. 1994. Influence of peptides, amino acids and urea on microbial activity in the rumen of sheep receiving grass hay and on the growth of rumen bacteria in vitro. Anim. Feed Sci. Technol. 49(1-2): 151-161.

46. Theodorou, M. K.; Williams, B. A.; Dhanoa, M. S.; McAllan, A. B.; France, J. 1994. A simple gas production method using a pressure transducer to determine the fermentation kinetics of ruminant feeds. Anim. Feed Sci. Technol. 48(3-4): 185-197.

47. Torrentera, N.; Carrasco, R.; Salinas-Chavira, J.; Plascencia, A.; Zinn, R. A. 2017. Influence of methionine supplementation of growing diets enriched with lysine on feedlot performance and characteristics of digestion in Holstein steer calves. Asian-Australas. J. Anim. Sci. 30(1): 42-50.

48. Van Soest, P. V.; Robertson, J. B.; Lewis, B. A. 1991. Methods for dietary fiber, neutral detergent fiber, and nonstarch polysaccharides in relation to animal nutrition. J. Dairy Sci. 74(10): 3583-3597.

49. Wang, Y.; McAllister, T. A.; Yanke, L. J.; Xu, Z. J.; Cheeke, P. R.; Cheng, K. J. 2000. In vitro effects of steroidal saponins from Yucca schidigera extract on rumen microbial protein synthesis and ruminal fermentation. J. Sci. Food Agric. 80(14): 2114-2122.

50. Wani, S. A.; Kumar, P. 2018. Fenugreek: A review on its nutraceutical properties and utilization in various food products. J. Saudi Society Agric Sci. 17(2): 97-106.

\section{ACKNOWLEDGMENTS}

The authors thank Nuproxa México, Nuproxa Switzerland, and Indian Herbs Co for donating herbal products and Ray Jones for edition and contributions for the manuscript.

Thanks are also extended to the Programa Cátedras CONACYT, of which Dr. Ma. Eugenia de la Torre

H. is part, commissioned at UAM Xochimilco for the development of the project No. 250 "Alternative strategies to reduce methane emissions by modifying the ruminal microbial community".

Finally, thanks are also extended to PhD program in Animal and Agricultural Sciences. Universidad Autónoma Metropolitana - Unidad Xochimilco. 